\title{
Elhízott populációra jellemző talpnyomásminták vizsgálata
}

\author{
Leidecker Eleonóra $^{1}$ - Kellermann Péter dr. ${ }^{2}$ \\ Galambosné Tiszberger Mónika dr. ${ }^{3}$ - Molics Bálint dr. ${ }^{1}$ \\ Bohner-Beke Aliz ${ }^{4}$. Nyárády József dr. ${ }^{1}$ - Kránicz János dr. ${ }^{1}$ \\ ${ }^{1}$ Pécsi Tudományegyetem, Egészségtudományi Kar, Fizioterápiás és Sporttudományi Intézet, Pécs \\ ${ }^{2}$ Szegedi Tudományegyetem, Általános Orvostudományi Kar, Ortopédiai Klinika, Szeged \\ ${ }^{3}$ Pécsi Tudományegyetem, Közgazdaságtudományi Kar, Közgazdasági és Ökonometriai Intézet, Pécs \\ ${ }^{4}$ Eötvös József Főiskola, Baja
}

\begin{abstract}
Bevezetés: A testsúlynak jelentős szerepe van a láb megnövekedett terhelésében és a nyomásminták változásaiban, de a változások eloszlása pontosan nem ismert. Célkitüzés: Jelen kutatás célja volt normál és kóros testtömegindexű egyének talpnyomásmintáinak vizsgálata, hogy közelebbi képet kapjunk a regionális plantaris terhelés változásairól. Módszer: A vizsgálatnak 180 alanya volt, a talpnyomás mérése dinamikus pedobarográffal történt. A talp 8 anatómiai régióját vizsgáltuk, az alábbi paraméterek függvényében: kontakt terület, csúcsnyomás, maximális erô. Eredmények: A láb középső területén és metatarsusok alatt jelentősen nagyobb csúcsnyomás jellemző az elhízott egyénekre $(\mathrm{p}<0,001)$. A maximális erőértékek az ujjaknál alacsonyabb $(\mathrm{p}<0,001)$, a kontakt terület adatai a totális talpterületen $(\mathrm{p}<0,001)$ és a középső talp területén szignifikánsan nagyobb értékeket mutatott az elhízottak csoportjában $(\mathrm{p}<0,001)$. Következtetések: Elhízás hatására kóros mértékű terhelésnövekedés következik be a láb középső területén, különösen a medialis oldalon és a metatarsusok alatt. Orv. Hetil., 2016, 157(48), 1919-1925.
\end{abstract}

Kulcsszavak: elhízás, talpnyomásminták, medialis hosszboltozat

\section{Analysis of plantar pressure patterns among obese population}

Introduction: Although the role of body weight on foot health and load has been widely documented in research, the effect of the extra load due to body weight on plantar pressure characteristics is not well known. Aim: The aim of this study was to evaluate the impact of obesity on plantar pressure patterns among the working-age population. Method: 180 participants were involved. Two groups were evaluated according to body mass index categories regarding eight regions of the plantar area, focusing on the following parameters: contact area, maximum pressure and peak pressure. Results: Compared with non-obese subjects, the peak pressure was the highest on the midfoot $(\mathrm{p}<0.001)$ and the forefoot $(\mathrm{p}<0.001)$. Regarding the maximum force, significant statistical difference was detected on the toes $(\mathrm{p}<0.001)$, with a value lower among the obese group. The contact area on the total foot and the midfoot was lower among the non-obese subjects $(\mathrm{p}<0.001)$. Conclusions: Loading is greatly increasing on the whole plantar area, especially at the midfoot and the forefoot region.

Keywords: obesity, pressure patterns, midfoot

Leidecker, E., Kellermann, P., G. Tiszberger, M., Molics, B., Bohner-Beke, A., Nyárády, J., Kránicz, J. [Analysis of plantar pressure patterns among obese population]. Orv. Hetil., 2016, 157(48), 1919-1925.

(Beérkezett: 2016. június 3.; elfogadva: 2016. augusztus 9.)

\section{Rövidítések}

$\mathrm{BMI}=$ body mass index; lat. = lateralis; $\mathrm{LL}=$ lateralis lábközép; LMT = lateralis metatarsusok; LS = lateralis sarok; LU = lateralis lábujjak; med. = medialis; $\mathrm{ML}=$ medialis lábközép; $M M T=$ medialis metatarsusok; $\mathrm{MS}=$ medialis sarok; $\mathrm{MU}=$ medialis lábujjak; TOT $=$ teljes talp
Az elhízás mint önálló betegségkategória jelenik meg a nemzetközi irodalomban, amely további súlyos kóroki tényezőként szerepel több mint 30 kóros elváltozás esetében, beleértve a láb egyes elváltozásait is [1-4]. Hatása komplex a láb funkciójára: a szöveti szintű kóros folya- 
matok és a megváltozott testtartás és járáskinematika mind befolyásoló tényezőként szerepel, idővel a láb strukturális elváltozása következhet be $[5,6]$. A láb tartási rendellenességei megjelenhetnek, mint pes planus vagy dinamikus funkcionális pronált lábtartás, amelyeket strukturális deformitások váltanak fel $[7,8]$. Elhízottaknál a boka és a láb elváltozásai közé tartoznak a sarokfájdalom, plantaris fascitis, metatarsalgia, stresszfractura [9]. Az elhízáshoz kapcsolódó kórképek jelentős társadalmi és gazdasági terhet jelentenek a fejlett országokban és hazánkban is [10-14], ami komoly kihívás elé állítja az egészségügyi rendszer finanszírozásáért felelős intézményeket [15-19].

A korábban végzett vizsgálatok eredményei megegyeznek abban, hogy a testsúlynak jelentős szerepe van a láb megnövekedett terhelésében és a nyomásminták változásaiban, de a változások eloszlása pontosan nem ismert $[6,20]$. Irodalmi adatok a talpi hosszanti ív megnövekedett csúcsnyomásáról számolnak be [5, 20-23]. Az előláb megnövekedett terhelése elhízottaknál nem egyértelmú a korábbi vizsgálatok eredményei alapján: Hills és mtsai, valamint Teh és mtsai az elóláb fokozott terhelését írták le, míg Birtane és mtsai vizsgálatukban nem erôsítették meg ezeket az adatokat [5, 20, 21]. A láb hátsó részének fokozott terheléséről többen beszámoltak elhízottaknál [5, 20, 24], de Teh és mtsai [21] - ugyan statikus mérést végeztek - nem találtak fokozott terhelést a sarok alatt, annak ellenére, hogy súlyosan elhízottakat vizsgáltak.

Ma már a talp nyomásviszonyainak ismerete nélkülözhetetlen a lábelváltozások modern ellátásában, többek között az egyedi talpbetétek, ortézisek, gyógycipők tervezésekor [24, 25]. Az elhízás magas prevalenciája a népességben szükségessé teszi hatásának mélyebb vizsgálatát a láb terhelésére és a talpnyomásmintákra. A klinikai gyakorlatban különösen olyan esetekben látjuk jelentőségét, mint például a diabeteses neuropathia és a láb Charcot-deformitása, amely esetekben az elhízás további súlyosbító tényezőként szerepel. Ismert kiegészítő tényezőként megállapítható, hogy a női nem szignifikánsan összefüggésbe hozható a gyakoribb fájdalmas lábelváltozásokkal, amely folyamatban az elhízás rizikófaktorként szerepel [7, 26].

1. táblázat $\mid$ A vizsgált populáció $(n=180)$ antropometriai jellemzői (átlag; szórás)

\begin{tabular}{lllll}
\hline & $\begin{array}{l}\text { Normál } \\
\text { BMI-kategória } \\
(\mathrm{n}=142)\end{array}$ & $\begin{array}{l}\text { Elhízott } \\
\text { BMI-kategória } \\
(\mathrm{n}=38)\end{array}$ & $\mathrm{F}$ & $\mathrm{p}$ \\
\hline Nem & $\begin{array}{l}\text { Férfi }=39 ; \\
\text { nő }=103\end{array}$ & $\begin{array}{l}\text { Férfi }=13 ; \\
\text { nő }=25\end{array}$ & 10,6 & 0,01 \\
Életkor & $38,45 \pm 10,31$ & $43,11 \pm 10,64$ & 4,57 & 0,01 \\
Testsúly $(\mathrm{kg})$ & $63,75 \pm 10,47$ & $91,98 \pm 10,96$ & 168 & $<0,01$ \\
Magasság $(\mathrm{cm})$ & $169,93 \pm 9,90$ & $167,93 \pm 9,92$ & 2,73 & 0,07 \\
BMI $\left(\mathrm{kg} / \mathrm{m}^{2}\right)$ & $21,90 \pm 1,91$ & $32,79 \pm 2,42$ & 690 & $<0,01$ \\
\hline
\end{tabular}

Jelen kutatás célja volt normál és kóros testtömegindexú (BMI) egyének talpnyomásmintáinak vizsgálata, hogy közelebbi képet kapjunk a regionális plantaris terhelés változásairól elhízott egyéneknél. Az eredmények mélyebb megértése érdekében további célul tűztük ki a nem és BMI együttes hatásának vizsgálatát a talp terhelési viszonyaira.

\section{Módszer}

\section{A vizsgálat résztvevöi}

A vizsgálatba 180 fó, munkaképes korosztályba tartozó felnőtt került bevonásra ( 52 férfi és 128 nő). A felmérést az Egyesített Egészségügyi Intézmények Pécsi Védőnői Szolgálat és a Magyar Posta Pécsi Kirendeltségének dolgozói körében végeztük.

A vizsgált populáció antropometriai adatai szerint az átlagéletkor 38,83 \pm 10,5 év, az átlag-BMI 24,18 \pm 4,95 $\mathrm{kg} / \mathrm{m}^{2}$ volt. A BMI átlagértéke a normál súlyúak csoportjában $\left(\mathrm{n}=142\right.$ fó) $21,90 \pm 1,91 \mathrm{~kg} / \mathrm{m}^{2}$ volt, az elhízottak csoportjában $\left(\mathrm{n}=32\right.$ fó) $32,79 \pm 2,42 \mathrm{~kg} / \mathrm{m}^{2}$ volt (1. táblázat). A BMI kalkulációja a magyar szakmai protokoll ajánlása szerint történt [27].

Összesen 360 láb vizsgálatát végeztük el. Kizárási kritériumként határoztuk meg az alsó végtag és a láb direkt és indirekt elváltozásait: a láb és az alsó végtag veleszületett és szerzett deformitásait, végtaghosszkülönbséget, reumás vagy diabeteses lábat, varicositast, perifériás artériás keringési elégtelenséget, neurológiai kórképeket, traumát vagy sebészeti beavatkozást az alsó végtagon vagy lábon, az egyén kooperációs, illetve kognitív képességének zavarát.

\section{Vizsgálati módszer}

A különböző BMI-kategóriájú csoportok talpnyomásának mérése Novel 101B EMED SF típusú komputeres, dinamikus pedobarográffal történt. A vizsgálathoz 102 $\mathrm{H}$ (4 szenzor $/ \mathrm{cm}^{2}, 50$ mérés/s) platformot vagy érzékelólemezt használtunk. Az úgynevezett „mid-gait” módszer alkalmazását követtük $[28,29]$. A platform egy $8 \mathrm{~m}$ hosszú és $1 \mathrm{~m}$ széles járdába épített, középen pozicionált, így a járás folyamatában történt a talp adatainak érzékelése. A járás dinamikája a méréskor egyenletes volt, irányváltoztatás, megtorpanás, lassulás nélkül, ellenkező esetben a járás sebességének változása a talpnyomásértékeket 7\%-ban torzíthatja [30,31]. A mérésekre cipő nélkül került sor. Ha a vizsgált alany rosszul lépett, kilépett a lemezről vagy nem a teljes talpról készült felvétel, a mérést megismételtük. Minden korrekt lépésről, illetve lábról egy felvétel készült. A talpnyomás-paraméterek feldolgozása EMED szoftverrel történt.

A talp régióját 8 maszkra, területre osztottuk: lateralis sarok, medialis sarok, lateralis lábközép, medialis lábközép, lateralis metatarsusok, medialis metatarsusok, lateralis lábujjak, medialis lábujjak (1. ábra). 


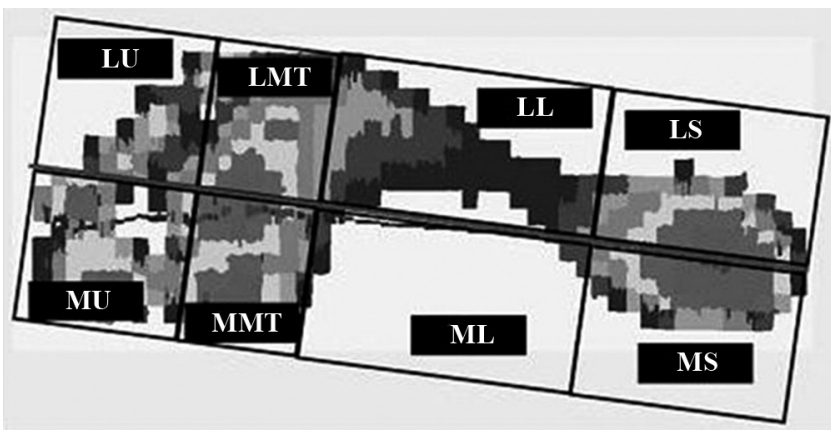

1. ábra

A talp vizsgált nyolc területe

$\mathrm{LL}=$ lateralis lábközép; LMT = lateralis metatarsusok; $\mathrm{LS}=$ lateralis sarok; $\mathrm{LU}=$ lateralis lábujjak; $\mathrm{ML}=$ medialis lábközép $\mathrm{MMT}=$ medialis metatarsusok; $\mathrm{MS}=$ medialis sarok; $\mathrm{MU}=$ medialis lábujjak

A következő paraméterek vizsgálata történt a maszkokon belül: kontakt terület $\left(\mathrm{cm}^{2}\right)$, csúcsnyomás $\left(\mathrm{N} / \mathrm{cm}^{2}\right)$, maximális erő $(\mathrm{N})$. A maximális erő értékét normalizáltuk a testsúlyhoz, a kontakt területet a totál kontakt területhez.

A vizsgálat a dél-dunántúli Regionális Kutatásetikai Bizottság jóváhagyásával történt (engedély száma: 3422).

\section{Statisztikai elemzés}

A szignifikáns különbségek kimutatására kétmintás t-próbát alkalmaztunk. Ugyanakkor, mivel a normalitásra vonatkozó előfeltétel néhány esetben nem teljesül, az eredményeket nemparaméteres próbával (Mann-Whitney-próba) is ellenőriztük. A kétféle módszer egybecsengó végeredményeket mutatott.

A BMI-kategória hatásával kapcsolatban szükségesnek tartottuk azt is megvizsgálni, hogy kimutatható-e a nem és a BMI-kategória közötti interaktív hatás a talpnyomásértékek tekintetében. Ehhez kétutas varianciaanalízist (kétutas ANOVA) végeztünk, amelyben a BMI-kategóriák és a nem voltak a minőségi ismérvek és a különböző talpnyomás-indikátorok a mennyiségi ismérvek. A 3. táblázat a különböző csoportosításokhoz tartozó leíró statisztikák mellett a kétutas ANOVA-val nyert szignifikanciaértékeket (p-értékeket) is tartalmazza. A kétutas ANOVA alkalmazhatóságának előfeltételeit is megvizsgáltuk az adatállományon. A normalitás teszteléséhez Shapiro-Wilk-tesztet, a varianciák egyezőségének vizsgálatához pedig Levene-tesztet alkalmaztunk. A felhasznált szoftver: IBM SPSS Statistics 20. Az alkalmazott szignifikanciaszint minden esetben $5 \%$ volt.

\section{Eredmények}

\section{BMI szerinti eredmények}

A csúcsnyomás a totál talpterület alatt szignifikánsan nagyobb volt az elhízottak csoportjában, mint a normál súlyúaknál (eltérés: $8,5 \%, p=0,009$ ). A láb középső területén (eltérés: lat.: $33,5 \%, \mathrm{p}<0,001$; eltérés: med.: $34 \%$, $\mathrm{p}<0,001$ ) és a metatarsusoknál (eltérés: lat.: 22,5\%, $\mathrm{p}<0,001$; eltérés: med.: $15 \%, \mathrm{p}<0,001)$ szintén nagyobb csúcsnyomást rögzítettünk az elhízott egyéneknél. Szignifikánsan nagyobb terhelést mértünk a saroknál, lateralisan az elhízottaknál (eltérés: 17,5\%,p<0,001) (2. táblá$z a t)$.

A maximális erőértékek tekintetében a láb középső területén és az ujjaknál találtunk szignifikáns különbségeket. Elhízottaknál a láb középső területén nagyobb (eltérés: lat.: $22 \%$; $<<0,001$; eltérés: med.: $31 \%, \mathrm{p}<0,001)$, az ujjaknál jelentősen kisebb értékeket (eltérés: lat.: $-54 \%$, p<0,001; eltérés: med.: $-26,5 \%, p<0,001)$ mértünk.

A kontakt területadatok a totál talpterületen (eltérés: $9 \%, \mathrm{p}<0,001)$ és a középső talp területén szignifikánsan nagyobb értékeket mutattak az elhízott csoportban (eltérés: lat.: $10 \%, \mathrm{p}<0,001$; eltérés: med.: $24 \%, \mathrm{p}<0,001)$, míg szignifikánsan alacsonyabb értékeket a medialis saroknál, a láb elülső részén és az ujjak területén $(\mathrm{p}<0,05)$ találtunk (2. táblázat).

\section{A nem és a BMI együttes hatása}

A BMI és a nem együttes hatásával kapcsolatban a vizsgált paraméterek nem mutattak szignifikáns eltérést a legtöbb talpi régióban. A medialis ujjak területén volt kimutatható interakció szignifikánsan alacsonyabb értékekkel a csúcsnyomás-paraméterekben elhízott nőknél, mint elhízott férfiaknál $(\mathrm{p}=0,021)$. Együttes hatás volt még megfigyelhető a maximális erő vizsgálatakor a medialis saroknál $(\mathrm{p}=0,021)$ és a lateralis ujjaknál $(\mathrm{p}=0,023)$, az elhízott nőknél alacsonyabb értékekkel, mint az elhízott férfiaknál (3. táblázat).

\section{Megbeszélés}

Tanulmányunk célja volt az elhízott és normál súlyú populáció plantaris terhelési mintáit összehasonlítani. A nemzetközi adatokkal egybehangzóan eredményeink arra engednek következtetni, hogy az elhízás talpnyomásviszonyokat befolyásoló hatása jelentős, a láb terhelése szignifikánsan fokozódik az ujjak kivételével az egész lábon, de különösen a láb középső és elülső területén. Ugyanakkor a BMI és a nem együttes hatása a legtöbb talpterületen nem állapítható meg.

\section{A BMI hatásának vizsgálata}

Adataink arra utalnak, hogy elhízottaknál kórosan terhelt talpterületnek tekinthető a láb középső régiója, ezen belül is a medialis terület, ahol a csúcsnyomás (34\%) jelentősen megnövekedett a nem elhízott egyénekéhez képest. Vizsgálatunk adatai közelítenek Birtane és Tuna, valamint Menz és mtsai eredményeihez [20, 22]. Érdekes megállapítást tettek Monterio és mtsai: elhízott egyének- 


\begin{tabular}{|c|c|c|c|c|c|c|c|c|}
\hline & & \multicolumn{2}{|c|}{$\begin{array}{l}\text { Normál BMI-kategória } \\
\qquad(\mathrm{n}=142)\end{array}$} & \multicolumn{2}{|c|}{$\begin{array}{l}\text { Elhízott BMI-kategória } \\
\qquad(\mathrm{n}=38)\end{array}$} & \multirow[b]{2}{*}{ Különbség (\%) } & \multirow[b]{2}{*}{$\mathrm{t}$} & \multirow[b]{2}{*}{ p-érték } \\
\hline & & Átlag & Szórás & Átlag & Szórás & & & \\
\hline \multirow[t]{9}{*}{ Maximális erő $(\mathrm{N})$} & Totál & 16,4 & 1,3 & 16,0 & 1,3 & $-2,38 \%$ & 2,21 & 0,028 \\
\hline & LS & 2,0 & 1,0 & 1,9 & 0,8 & $-5,65 \%$ & 1,00 & 0,32 \\
\hline & MS & 7,2 & 1,4 & 6,2 & 1,0 & $-15,85 \%$ & 6,75 & 0,000 \\
\hline & LL & 2,3 & 1,3 & 2,9 & 1,3 & $22,21 \%$ & $-3,94$ & 0,000 \\
\hline & ML & 1,0 & 0,6 & 1,4 & 0,7 & $30,77 \%$ & $-5,27$ & 0,000 \\
\hline & LMT & 4,6 & 1,4 & 4,7 & 1,3 & $2,70 \%$ & $-0,73$ & 0,467 \\
\hline & MMT & 7,4 & 1,5 & 7,2 & 1,6 & $-2,63 \%$ & 0,95 & 0,344 \\
\hline & $\mathrm{LU}$ & 0,7 & 0,4 & 0,5 & 0,2 & $-53,73 \%$ & 7,27 & 0,000 \\
\hline & $\mathrm{MU}$ & 4,3 & 1,4 & 3,4 & 1,0 & $-26,62 \%$ & 6,26 & 0,000 \\
\hline \multirow[t]{9}{*}{ Kontakt terület (\%) } & Totál & 3,2 & 0,3 & 3,5 & 0,3 & $9,12 \%$ & $-7,49$ & 0,000 \\
\hline & LS & 7,0 & 2,3 & 6,8 & 1,8 & $-1,73 \%$ & 0,47 & 0,636 \\
\hline & MS & 16,9 & 2,4 & 16,2 & 2,1 & $-4,23 \%$ & 2,25 & 0,025 \\
\hline & LL & 15,9 & 4,3 & 17,7 & 3,0 & $10,18 \%$ & $-3,45$ & 0,001 \\
\hline & ML & 7,3 & 3,3 & 9,5 & 3,9 & $23,82 \%$ & $-5,14$ & 0,000 \\
\hline & LMT & 15,0 & 1,9 & 14,2 & 1,6 & $-5,91 \%$ & 3,53 & 0,000 \\
\hline & MMT & 19,5 & 2,4 & 18,6 & 1,8 & $-4,90 \%$ & 3,65 & 0,000 \\
\hline & $\mathrm{LU}$ & 4,6 & 1,5 & 4,2 & 1,1 & $-9,13 \%$ & 2,43 & 0,016 \\
\hline & MU & 14,4 & 1,8 & 13,3 & 1,5 & $-8,87 \%$ & 5,18 & 0,000 \\
\hline \multirow[t]{9}{*}{ Csúcsnyomás $\left(\mathrm{N} / \mathrm{cm}^{2}\right)$} & Totál & 82,2 & 21,6 & 89,7 & 24,1 & $8,33 \%$ & $-2,61$ & 0,009 \\
\hline & LS & 32,6 & 9,3 & 39,5 & 8,3 & $17,42 \%$ & $-5,85$ & 0,000 \\
\hline & MS & 43,7 & 12,7 & 45,4 & 9,6 & $3,66 \%$ & $-1,24$ & 0,216 \\
\hline & LL & 21,2 & 14,2 & 31,9 & 16,8 & $33,51 \%$ & $-5,61$ & 0,000 \\
\hline & ML & 17,4 & 5,6 & 26,4 & 5,3 & $34,26 \%$ & $-12,58$ & 0,000 \\
\hline & LMT & 49,7 & 20,6 & 64,3 & 21,7 & $22,65 \%$ & $-5,40$ & 0,000 \\
\hline & MMT & 65,7 & 22,5 & 77,1 & 24,8 & $14,80 \%$ & $-3,84$ & 0,000 \\
\hline & $\mathrm{LU}$ & 26,3 & 13,4 & 24,7 & 14,3 & $-6,61 \%$ & 0,93 & 0,353 \\
\hline & $\mathrm{MU}$ & 64,6 & 25,4 & 70,7 & 28,9 & $8,57 \%$ & $-1,66$ & 0,099 \\
\hline
\end{tabular}

$\mathrm{LL}=$ lateralis lábközép; $\mathrm{LMT}=$ lateralis metatarsusok; $\mathrm{LS}=$ lateralis sarok; $\mathrm{LU}=$ lateralis lábujjak; $\mathrm{ML}=$ medialis lábközép; $\mathrm{MMT}=$ medialis metatarsusok; $\mathrm{MS}=$ medialis sarok; $\mathrm{MU}=$ medialis lábujjak.

nél a nélkül is megfigyelhető a láb középső területének csúcsnyomás-emelkedése, hogy nem változik a láb struktúrája, illetve változatlan a dinamikus posture index [32]. Tanulmányunknak nem volt tárgya, ezért csak egyetérthetünk Monterio és mtsai [32], illetve Teh és mtsai [21] feltételezésével: amikor az ívek alkalmazkodóképessége már nem érvényesül a testsúlyterheléssel szemben, megnő a terhelés a láb középső részén. Ugyanakkor Hills és mtsai [5], valamint Butterwort és mtsai [7] szerint a láb középső területén megnövekedett terhelés elhízottaknál a lábstruktúra diszfunkciójára, a hosszanti ív süllyedésére utal. A kontakt területet vizsgálva szintén a láb középső, medialis területén találtuk a legnagyobb különbséget, elhízottaknál magas értékekkel, hasonlóan Teh és mtsai vizsgálati eredményeihez [21]. Wearing és mtsai szerint a test zsírtömege és a lábstruktúra megváltozása állhat a nagyobb kontakt terület hátterében [9].

Korábbi tanulmányok az előláb fokozott terheléséről számolnak be elhízottaknál [5, 33-35]. Vizsgálatunkban is a metatarsusok alatt a csúcsnyomás elhízottaknál jelentősen magasabb értékeket mutatott, lateralisan $22 \%$-kal, medialisan 15\%-kal, mint a normál súlyú alanyoknál. Birtane és Tuna statikus mérések során, álló helyzetben találtak hasonló eredményeket, de dinamikus mérést alkalmazva már nem, ugyan alacsonyabb BMI kategóriájú résztvevôket vizsgáltak (BMI: $\left.32,2 \mathrm{~kg} / \mathrm{m}^{2}\right)$ [20]. Az elóláb fokozott terhelését a testtömegközéppont megváltozott helyzetével támasztják alá [21]. Hillstrom és 
Leíró statisztika és a kétutas varianciaanalízis eredményei a különböző talpnyomásmutatókon (maximális erő, csúcsnyomás, kontakt terület) BMI-kategóriák (normál-elhízott) és nemek szerint, nyolc talpterületen

\begin{tabular}{|c|c|c|c|c|c|c|c|c|c|c|c|c|}
\hline & & \multicolumn{2}{|c|}{$\begin{array}{c}\text { Férfi - normál } \\
\text { súlyú }\end{array}$} & \multicolumn{2}{|c|}{ Férfi - elhízott } & \multicolumn{2}{|c|}{$\begin{array}{c}\text { Nő - normál } \\
\text { súlyú }\end{array}$} & \multicolumn{2}{|c|}{ Nő - elhízott } & \multicolumn{3}{|c|}{ Kétutas ANOVA p-érték } \\
\hline & & Átlag & Szórás & Átlag & Szórás & Átlag & Szórás & Átlag & Szórás & Nem & BMI & Interakció \\
\hline \multirow[t]{9}{*}{ Maximális erő $(\mathrm{N})$} & Totál & 15,70 & 1,05 & 15,67 & 0,75 & 16,62 & 1,35 & 16,15 & 1,52 & 0,000 & 0,162 & 0.212 \\
\hline & LS & 1,85 & 1,04 & 1,91 & 0,71 & 2,02 & 1,03 & 1,85 & 0,79 & 0,719 & 0,673 & 0,385 \\
\hline & MS & 6,77 & 1,19 & 6,37 & 1,16 & 7,33 & 1,42 & 6,10 & 0,99 & 0,425 & 0,000 & 0,021 \\
\hline & LL & 2,41 & 1,50 & 2,65 & 1,15 & 2,23 & 1,18 & 3,07 & 1,33 & 0,481 & 0,002 & 0,089 \\
\hline & ML & 0,83 & 0,52 & 1,20 & 0,58 & 1,02 & 0,63 & 1,49 & 0,78 & 0,006 & 0,000 & 0,544 \\
\hline & LMT & 4,65 & 1,33 & 4,55 & 1,03 & 4,60 & 1,40 & 4,84 & 1,42 & 0,524 & 0,717 & 0,347 \\
\hline & MMT & 7,04 & 1,37 & 6,87 & 1,31 & 7,48 & 1,58 & 7,33 & 1,66 & 0,033 & 0,450 & 0,975 \\
\hline & $\mathrm{LU}$ & 0,60 & 0,32 & 0,50 & 0,29 & 0,75 & 0,38 & 0,44 & 0,19 & 0,335 & 0,000 & 0,023 \\
\hline & MU & 4,00 & 1,48 & 3,74 & 0,98 & 4,47 & 1,36 & 3,27 & 1,04 & 0,999 & 0,000 & 0,010 \\
\hline \multirow[t]{9}{*}{ Csúcsnyomás $\left(\mathrm{N} / \mathrm{cm}^{2}\right)$} & Totál & 82,44 & 21,03 & 89,88 & 22,12 & 82,10 & 21,88 & 89,54 & 25,26 & 0,911 & 0,016 & 0,999 \\
\hline & LS & 32,67 & 8,34 & 40,77 & 9,00 & 32,56 & 9,66 & 38,78 & 7,86 & 0,404 & 0,000 & 0,455 \\
\hline & MS & 43,69 & 11,02 & 47,42 & 11,20 & 43,73 & 13,36 & 44,32 & 8,62 & 0,362 & 0,199 & 0,350 \\
\hline & LL & 22,79 & 14,48 & 28,38 & 14,89 & 20,66 & 14,09 & 33,80 & 17,61 & 0,421 & 0,000 & 0,064 \\
\hline & ML & 17,18 & 6,70 & 25,15 & 5,79 & 17,42 & 5,21 & 27,04 & 4,92 & 0,168 & 0,000 & 0,283 \\
\hline & LMT & 52,55 & 17,73 & 59,62 & 16,79 & 48,62 & 21,57 & 66,66 & 23,67 & 0,588 & 0,000 & 0,057 \\
\hline & MMT & 65,12 & 21,23 & 71,81 & 21,17 & 65,90 & 23,03 & 79,84 & 26,31 & 0,166 & 0,001 & 0,254 \\
\hline & $\mathrm{LU}$ & 23,62 & 11,80 & 27,58 & 20,24 & 27,35 & 13,89 & 23,20 & 9,76 & 0,864 & 0,959 & 0,030 \\
\hline & MU & 65,37 & 26,86 & 81,08 & 25,19 & 64,31 & 24,89 & 65,24 & 29,52 & 0,019 & 0,021 & 0,040 \\
\hline \multirow[t]{9}{*}{ Kontakt terület (\%) } & Totál & 3,29 & 0,36 & 3,68 & 0,37 & 3,15 & 0,33 & 3,43 & 0,27 & 0,000 & 0,000 & 0,243 \\
\hline & LS & 7,02 & 2,13 & 6,88 & 1,75 & 6,94 & 2,36 & 6,83 & 1,88 & 0,824 & 0,672 & 0,960 \\
\hline & MS & 17,08 & 2,45 & 16,13 & 2,26 & 16,82 & 2,42 & 16,24 & 1,98 & 0,828 & 0,020 & 0,569 \\
\hline & LL & 16,33 & 4,94 & 17,88 & 2,81 & 15,79 & 4,02 & 17,68 & 3,15 & 0,509 & 0,002 & 0,771 \\
\hline & ML & 6,60 & 3,20 & 8,77 & 3,51 & 7,52 & 3,31 & 9,94 & 4,00 & 0,027 & 0,000 & 0,798 \\
\hline & LMT & 15,46 & 1,82 & 14,73 & 1,35 & 14,86 & 1,90 & 13,90 & 1,67 & 0,005 & 0,001 & 0,645 \\
\hline & MMT & 19,46 & 2,47 & 18,45 & 1,75 & 19,51 & 2,36 & 18,65 & 1,83 & 0,692 & 0,003 & 0,801 \\
\hline & LU & 4,44 & 1,65 & 4,40 & 1,10 & 4,68 & 1,45 & 4,14 & 1,17 & 0,952 & 0,146 & 0,201 \\
\hline & MU & 14,20 & 1,81 & 13,18 & 1,14 & 14,54 & 1,82 & 13,32 & 1,66 & 0,325 & 0,000 & 0,668 \\
\hline
\end{tabular}

LL = lateralis lábközép; $\mathrm{LMT}=$ lateralis metatarsusok; $\mathrm{LS}=$ lateralis sarok; LU = lateralis lábujjak; $\mathrm{ML}=$ medialis lábközép; $\mathrm{MMT}=$ medialis metatarsusok; MS = medialis sarok; $\mathrm{MU}=$ medialis lábujjak.

mtsai [36] a láb megváltozott struktúrája nélkül - pes planus, pes cavus - megnövekedett talpnyomásértékeket írtak le elhízottaknál a metatarsusok régiójában. Úgy tûnik, hogy elhízott egyéneknél funkcionálisan is megemelkedett talpnyomásértékek jelennek meg a metatarsusoknál. Gravante és mtsai [33] vizsgálatában a kontakt terület az előlábon mutatott maximumértéket elhízottaknál, saját eredményeink szerint az előlábon emelkedett érték figyelhetô meg, de a maximumérték a láb középső, medialis területére lokalizálódik.

Teh és mtsai vizsgálatához hasonlóan, a saroknál a medialis oldalon jegyeztünk magasabb csúcsnyomásértékeket a nem elhízott alanyoknál, lateralisan az elhízottak fokozott sarokterhelése volt jellemző [21]. Messier szerint elhízottaknál a láb hátsó részének mozgása megnő sa- rokütéskor [37]. Korábbi tanulmányok szinte mindegyike beszámol a láb hátsó területének fokozott terhelésérôl elhízottaknál $[7,20,21,24]$. Arnold és mtsai egyszeri többlet-testsúlyterhelést vizsgálva is hasonló eredményt kaptak, szerintük a sarok érzékeny terület a lábon, kevésbé tud alkalmazkodni, ezért lehet gyakori a sarokfájdalom elhízottaknál [24]. Eredményeink alapján megjegyezzük, hogy elhízottaknál nem a sarok, hanem a láb középső területén mutattuk ki a legnagyobb terhelését.

$\mathrm{Az}$ ujjak alatt alacsonyabb maximális erőértéket jegyeztünk fel az elhízottak csoportjánál, hasonlóan mások vizsgálati eredményeihez [20, 21, 33]. Egyes tanulmányok szerint az ujjak kevésbé tekinthetők aktívnak a lesüllyedt hosszanti ívek miatt. 


\section{A nemek és a BMI együttes hatásának vizsgálata}

Jelen tanulmánynak nem volt tárgya, ugyanakkor ismert tény, hogy nóknél gyakoribbak a fájdalmas lábelváltozások, amely folyamatban az elhízás rizikótényezőként szerepel [7]. Vizsgálatunkban nem szignifikáns mértékű a nemek és a BMI együtthatása a plantaris nyomásparaméterekre a legtöbb talpterületen, amely adatok összefüggésben állnak Hills és mtsai vizsgálati eredményeivel. A nem és a BMI együttes hatása csak az ujjaknál található meg, elhízott nőknél alacsonyabb csúcsnyomásértékekkel, mint elhízott férfiaknál, de a medialis ujjaknál elhízott nőknél magasabb értékekkel, mint a normál súlyú női alanyoknál. A különbség hátterében funkcionális és strukturális tényezők egyaránt lehetségesek. Feltételezzük, hogy a nőkre gyakrabban jellemző halluxvalgus-deformitás befolyásolhatja az ujjaknál a terheléskülönbséget. Néhány korábbi tanulmány a hallux területén valgusdeformitás miatt alacsonyabb nyomásértékekról számolt be, amit a hallux diszfunkciójával és fájdalmával indokoltak $[7,38]$, mások nagyobb nyomásértékeket jegyeztek a deformitás miatt [39]. Amennyiben idősebb populációt vizsgálunk, valószínúsíthetően markánsabb különbséget kapunk a plantaris nyomásmintákban elhízott egyéneknél a nemek között.

\section{Vizsgálatunk korlátai}

Jelen kutatás egyik korlátjának tekintjük, hogy a nagy elemszámra tekintettel (360 láb) minden vizsgált alany lábáról egy felvétel készült, a tanulmányhoz elvégzett vizsgálatok időben korlátozottak voltak, ismétlésekre nem került sor. Ezt a megszorítást azonban tompítja, hogy a minta elemszáma meglehetősen magas, valamint az a tény, hogy az egyszeri vizsgálat inkább a kisebb különbségek felé torzít, vagyis nem vezet fals pozitív eredményekre a tetten érhetô eltérések szempontjából [40].

Egyetértünk Butterworth és mtsai megállapításával: a különböző tanulmányok eredményeinek összehasonlítása nehézkes, tekintettel arra, hogy több pedobarográffal végezték a vizsgálatokat, a láb regionális felosztása is más és más volt, illetve különböző BMI-értékek mellett végezték azokat [7].

\section{Következtetések}

Tanulmányunk arra hívja fel a figyelmet, hogy elhízás hatására kóros mértékű terhelésnövekedés következik be a láb középső területén, különösen medialisan és a metatarsusok alatt. Adataink szerint nem kell számítani nőknél és férfiaknál az elhízás eltérő hatására a lábon, a nemnek és a BMI-nek nincs szignifikáns együtthatása a plantaris nyomásparaméterekre a legtöbb talpterületen. Úgy gondoljuk, hogy a témában közölt eredmények so- kat segíthetnek a láb súlyos elváltozásainak kezelésében, figyelembe véve, hogy az érintett betegpopulációban az elhízás gyakorisága magas.

Anyagi támogatás: A közlemény megírása és a kutatómunka anyagi támogatásban nem részesült.

Szerzői munkamegosztás: L. E., K. J., NY. J.: A kézirat megszövegezése. M. B., L. E., Ny. J., B.-B. A.: Irodalomkutatás. G. T. M.: Statisztikai elemzések. L. E., K. P.: A vizsgálat lefolytatása. A cikk végleges változatát valamennyi szerző elolvasta és jóváhagyta.

Érdekeltségek: A szerzőknek nincsenek érdekeltségeik.

\section{Irodalom}

[1] Gregor, M. F., Hotamisligil, G. S.: Inflammatory mechanisms in obesity. Annu. Rev. Immunol., 2011, 29, 415-445.

[2] Nwudu, V. C.: Systematic review and meta-analysis on obesitymortality association and age. Obes. Res. Clin. Pract., 2015, 9(3), 305-306.

[3] Simonyi, G., Kollár, R.: Obesity and hypertension. [Elhízás és hypertonia.] Orv. Hetil., 2013, 154(44), 1736-1742. [Hungarian]

[4] Hagymási, K., Tulassay, Zs.: Role of obesity in colorectal carcinogenesis. [Az elhízás szerepe vastagbéldaganatok kialakulásában.] Orv. Hetil., 2007, 148(51), 2411-2416. [Hungarian]

[5] Hills, A. P., Hennig, E. M., Byrne, N. M., et al.: The biomechanics of adiposity - structural and functional limitations of obesity and implications for movement. Obes. Rev., 2002, 3(1), 35-43.

[6] Vela, S. A., Lavery, L. A., Armstrong, D. G., et al.: The effect of increased weight on peak pressures: implications for obesity and diabetic foot pathology. J. Foot Ankle Surg., 1998, 37(5), 416420 .

[7] Butterworth, P. A., Landorf, K. B., Gilleard, W., et al.: The association between body composition and foot structure and function: a systematic review. Obes. Rev., 2014, 15(4), 348-357.

[8] Cimolin, V., Capodaglio, P., Cau, N., et al.: Foot-type analysis and plantar pressure differences between obese and nonobese adolescents during upright standing. Int. J. Rehabil. Res., 2016, $39(1), 87-91$.

[9] Wearing, S. C., Hennig, E. M., Byrne, N. M., et al.: The biomechanics of restricted movement in adult obesity. Obes. Rev., 2006, 7(1), 13-24.

[10] Spieker, E. A., Pyzocha, N.: Economic impact of obesity. Prim. Care, 2016, 43(1), 83-95.

[11] Iski, G., Rurik, I.: The estimated economic burden of overweight and obesity in Hungary. [Becslések a túlsúly és az elhízás hazai gazdasági terheiről.] Orv. Hetil., 2014, 155(35), 1406-1412. [Hungarian]

[12] Boncz, I., Sebestyén, A.: Financial deficits in the health services of the UK and Hungary. Lancet, 2006, 368(9539), 917-918.

[13] Endrei, D., Molics, B., Ágoston, I.: Multicriteria decision analysis in the reimbursement of new medical technologies: real-world experiences from Hungary. Value Health, 2014, 17(4), 487-489.

[14] Boncz, I., Vajda, R., Ágoston, I., et al.: Changes in the health status of the population of Central and Eastern European countries between 1990 and 2010. Eur. J. Health Econ., 2014, 15(Suppl. 1), 137-141.

[15] Boncz, I., Evetovits, T., Dózsa, Cs., et al.: The Hungarian Care Managing Organization pilot program. Value Health Regional., $2015,7 C, 27-33$. 
[16] Boncz, I., Nagy, J., Sebestyén, A., et al.: Financing of health care services in Hungary. Eur. J. Health Econ., 2004, 5(3), 252-258.

[17] Endrei, D., Zemplényi, A., Molics, B., et al.: The effect of performance-volume limit on the DRG based acute care hospital financing in Hungary. Health Policy, 2014, 115(2-3), 152-156.

[18] Endrei, D., Kollár, L., Bódis, J., et al.: Effects of performancevolume limit on the institutional financing of the Clinical Centre of the University of Pécs, Hungary. [A teljesítményvolumenkorlát hatása a Pécsi Tudományegyetem Klinikai Központ intézményi finanszírozására.] Orv. Hetil., 2010, 151(31), 12701274. [Hungarian]

[19] Boncz, I., Sebestyén, A.: Economy and mortality in Eastern and Western Europe between 1945-1990: the largest medical trial of history. Int. J. Epidemiol., 2006, 35(3), 796-797.

[20] Birtane, M., Tuna, H.: The evaluation of plantar pressure distribution in obese and non-obese adults. Clin. Biomech., 2004, 19(10), 1055-1059.

[21] Teh, E., Teng, L. F., Acharya, U. R., et al.: Static and frecquency domain analysis of plantar pressure distribution in obese and non-obese subjects. J. Bodywork Mov. Ther., 2006, 10(2), 127133.

[22] Menz, H. B., Morris, M. E.: Clinical determinants of plantar forces and pressures during walking in older people. Gait Posture, 2006, 24(2), 229-236.

[23] Tóth, K., Kellermann, P., Gyetvai, A.: Computer assisted dinamic pedobarography: A new method in the examination/analysis of the walking and the pressure distribution under the foot. II. The influence of different load into the pressure distribution of the foot and into walking measuring by different walking speed. [Dinamikus pedobarográfia: A járás dinamikájának és talpnyomáseloszlás változásának új vizsgálati lehetôsége. II. Terhelés hatása a járás dinamikájára és a talp nyomásviszonyainak eloszlására különböző járássebesség esetén.] Sportorv. Szemle, 1995, 36(3), 193-199. [Hungarian]

[24] Arnold, J. B., Causby, R., Pod, G. D., et al.: The impact of increasing body mass on peak and mean plantar pressure in asymptomatic adult subjects during walking. Diabet. Foot Ankle, 2010, 1, 10.3402/dfa.vli0.5518.

[25] Brown, D., Wertsch, J. J., Harris, G. F., et al.: Effect of rocker soles on plantar pressures. Arch. Phys. Med. Rehabil., 2004, 85(1), 81-86.

[26] Menz, H. B., Barr, E. L., Brown, W. J.: Predictors and persistence of foot problems in women aged 70 years and over: A prospective study. Maturitas, 2011, 68(1), 83-87.

[27] The professional protocol of the Ministry of Health. The diagnosis and treatment of obesity prepared by the College of Internal Medicine and the Hungarian Society for the study of Obesity. [Az Egészségügyi Minisztérium szakmai protokollja. Az elhízás diagnosztikája és kezelése. Készítette: A Belgyógyászati Szakmai Kollégium és a Magyar Elhízástudományi Társaság, 2008.]
http://www.kk.pte.hu/docs/protokollok/BELElhizas_P.pdf [Hungarian]

[28] Harrison, A. J., Folland, J. P.: Investigation of gait protocols for plantar pressure measurement of non-pathological subjects using a dynamic pedobarograph. Gait Posture, 1997, 6(1), 50-55.

[29] Wearing, S. C., Urry, S., Smeathers, J. E., et al.: A comparison of gait initiation and termination methods for obtaining plantar foot pressures. Gait Posture, 1999, 10(3), 255-263.

[30] Hennig, E. M., Staats, A., Rosenbaum, D.: Plantar pressure distribution patterns of young school children in comparison adults. Foot Ankle Int., 1995, 15(1), 35-40.

[31] Tóth, K., Kellermann, P., Gyetvai, A.: Computer assisted dinamic pedobarography: A new method in the examination/analysis of the walking and the pressure distribution under the foot. I. The influence of different speed into the pressure distribution during the walking. [Dinamikus pedobarográfia: A járás dinamikájának és talpnyomás-eloszlás változásának új vizsgálati lehetősége. I. Különböző járássebesség hatása a talpnyomás-viszony eloszlására és a járás dinamikájára.] Sportorv. Szemle, 1994, 35(4), 229240. [Hungarian]

[32] Monterio, M. A., Gabriel, R. E., Neves, E., et al.: Exercise effects in plantar pressure of postmenopausal women. Menopause, 2010, 17(5), 1017-1025.

[33] Gravante, G., Russo, G., Pomara, F., et al.: Comparison of ground reaction forces between obese and control young adults during quiet standing on a baropodometric platform. Clin. Biomech., $2003,18(8), 780-782$

[34] Kanatli, U., Yetkin, H., Simssek, A., et al.: Pressure distribution patterns under the metatarsal heads in healthy individuals. Acta Orthop. Traumatol. Turc., 2008, 42(1), 26-30.

[35] Butterworth, P. A., Urquhart, D. M., Landorf, K. B., et al.: Foot posture, range of motion and plantar pressure characteristics in obese and non-obese individuals. Gait Posture, 2015, 41(2), 465-469.

[36] Hillstrom, H. J., Song, J., Kraszewski, A. P., et al.: Foot type biomechanics part 1: structure and function of the asymptomatic foot. Gait Posture, 2013, 37(3), 445-451.

[37] Messier, S. P., Davies, A. B., Moore, D. T., et al.: Severe obesity: effects on foot mechanics during walking. Foot Ankle Int., 1994, 15(1), 29-34.

[38] Wen, J., Ding, Q., $\Upsilon_{u}, Z$., et al.: Adaptive changes of foot pressure in hallux valgus patients. Gait Posture, 2012, 36(3), 344-349.

[39] Martínez-Nova, A., Sánchez-Rodriguez, R., Pérez-Soriano, P., et al.: Plantar pressures determinants in mild hallux valgus. Gait Posture, 2010, 32, 425-427.

[40] Blalock, H. M.: Social Statistics. 2nd ed. McGraw-Hill, New York, 1979.

(Leidecker Eleonóra,

Pécs, Rét u. 4., 7623

e-mail: noran@etk.pte.hu) 